\title{
Design of Monitoring and Separating Dustbin System using Internet of Things
}

\author{
$1^{\text {st }}$ Rizal Mujaddid Irsyad \\ Dept. Electrical Engineering \\ Universitas Sebelas Maret \\ Surakarta, Indonesia \\ rizalmujaddidirsyad@student.uns.ac.id \\ $3^{\text {rd }}$ Annisa Larasati Febrianingrum \\ Dept. Electrical Engineering \\ Universitas Sebelas Maret \\ Surakarta, Indonesia \\ annisalarasatif@student.uns.ac.id
}

\author{
$2^{\text {nd }}$ Luqman Hadi Dwi Satryo \\ Dept. Electrical Engineering \\ Universitas Sebelas Maret \\ Surakarta, Indonesia \\ luqmanhadi07@student.uns.ac.id \\ $4^{\text {th }}$ Feri Adriyanto \\ Dept. Electrical Engineering \\ Universitas Sebelas Maret \\ Surakarta, Indonesia \\ feri.adriyanto@staff.uns.ac.id
}

\begin{abstract}
The growing population is causing a big problem in terms of waste. Garbage sorting efforts need to be made, especially the separation between organic and nonorganic garbage, so that non-organic garbage that can still be recycled is not contaminated by organic garbage containing water and oil. Moreover, it requires swift handling of trash bins that are full so that trash does not accumulate and become an epidemic. For that we need innovation in the form of technology that is able to overcome the se problems. This paper is designed IoT-based garbage for monitoring and separating dustbin. The design of garbage was made using Arduino UNO as a microcontroller that can monitor and sort garbage automatically. There are 2 stages in the garbage sorting process. The first stage is the metal and non-metal separation, and then the second stage is the organic and non-organic stages. When the trash is full, the trash can lid will be locked and then the system will send a notification to the garbage manager regarding the location/position of the trash and the weight of the trash. This research method includes 4 stages such as analysis of needs and working methods, design of hardware and software design, implementation, and finally testing of the design.
\end{abstract}

Keywords - garbage, waste management, garbage sorting, separting dustbin, internet of things

\section{INTRODUCTION}

Garbage has become a national problem so its management needs to be carried out comprehensively and in an integrated manner. To properly manage garbage, it requires knowledge of the types of garbage. For supporting "Pilah Sampah Dari Rumah" program launched by the Ministry of Environment and Forestry in 2019, the government needs to educate the public about garbage [1]. This education is necessary considering that Indonesia is the second-largest producer of plastic garbage in the world [2]. During the Covid-19 pandemic, the was te that we produce tends to be more than usual. masks, face shields, and other medical waste, most of which can only be used once, as well as increased online shopping activities and food delivery also contributed to the increase in waste generated during this pandemic [3]. Thus, we need a solution to sorting and managing waste.

Lack of public awareness in disposing of waste properly causing various types of waste, scatter in various places and cause unpleasant odors. Even if a trash can is full and is not immediately taken for disposal, it can cause garbage to continue to pile up, neglect, and the environment to look shabby. Garbage sorting efforts need to be made, especial the separation between organic and non-organic garbage so that non-organic garbage that can still be recycled is not contaminated by organic garbage containing water and oil. Moreover, it requires swift handling of trash bins that are full so that trash does not accumulate and become an epidemic. For that, we need innovation in the form of technology that can overcome these problems. However, is there any technology used to solve these waste management problems? Various countries have made innovations to solve the garbage problem, but most of the systems developed are only integrated with the garbage collection system. Even though various types of garbage are mixed in the trash. The sorting of plastic, non-plastic, recycled and household waste needs to be handled differently. For that we need innovation in the form of technology that is able to overcome these problems.

\section{BACKGROUNDS}

\section{A. Previous Studies}

Lately, a lot of research has been done to solve the problem of waste. This research is important to do to facilitate and educate the public about sorting waste and waste management so that later different types of waste can be processed according to their respective categories. Previous research was conducted by Dedi Setiawan (2014), entitled "Rancang Bangun Alat Pembuka dan Penutup Tong Sampah Otomatis Berbas is Mikrokontroler"[4]. Furthermore, Faisal (2017) has made a tool that can detect weight and full waste that is connected to an application on an Android Smartphone[5]. Further development has been carried out by Bioenable (2019) who proposes the smart city program to develop the Smart Bins Concept[6]. Furthermore, Sensoneo (2019) has also developed a waste monitoring system[7]. However, most of the systems developed are only integrated with the garbage collection system. Even though the garbage in the trash comes from various kinds of garbage. The sorting of plastic and non-plastic waste, recycled waste and household wasteneed to be handled differently.

\section{B. Garbage}

Garbage is something that cannot be separated from human life. Garbage is an item that the owner considers unused or disposed of by the previous owner, but for some people, waste can still be used or managed with the right procedures (Panji Nugroho, 2013)[8]. However, it will be a problemif it is not managed properly. 


\section{Waste Sorting}

Basically, in the waste management process, we must know the types of waste. There are various types of waste such as organic, non-organic or metal waste. This needs to be handled differently, and must be sorted according to type so that it is easy to manage. Then with this sorting it makes it easier to recycle back into other forms such as organic was te which can be processed into compost, then metals and non-organic materials are reprocessed.

\section{Waste Monitoring}

In waste management, officers need to check to avoid full trash cans. This is very important so that the trash cans do not over capacity and cause garbage to scatter around. However, most of the trash bins were full before the checkup day arrived so that they were overloaded and had the potential to disturb the surrounding community.

\section{TECHNICAL APPROACH}

\section{A. SchematicandDesign}

(1) This systemhas 3 main stages

(2) Open and close the trash automatically

(3) Sorting trash automatically

Automatic wastemonitoring

With the main components consisting of:

a) Microcontroller: Arduino Uno, Node Mcu

b) Ultrasonic sensor as person detectors detail

c) Servo as actuator

d) Proximity Sensor: Capacitive and Inductive as garbagetype detector

e) Load cell as waste weight counter

f) Infrared as full trash detector

g) Lipo-Battery: $9 \mathrm{~V}$ as a power supply for the system

All of these components hooked up as shown in Fig 1.

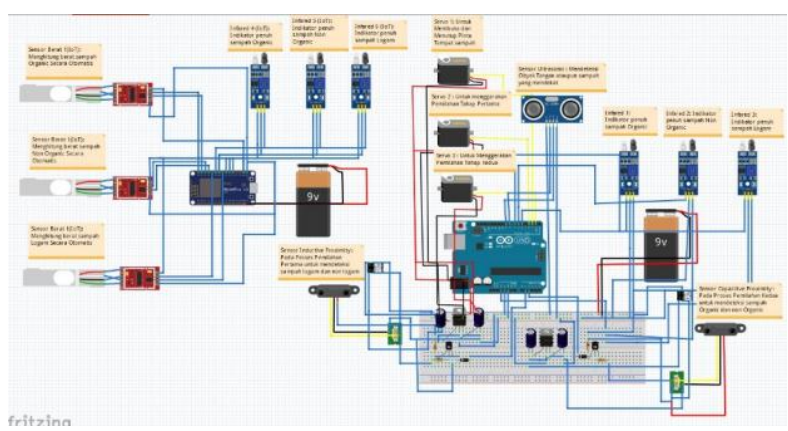

Fig 1. Schematic of Monitoring and Separating Dustbin System

Then for the design made from Hard Maple wood and acrylic glass, and 3D designs are made using the sketchup application, with results like this:

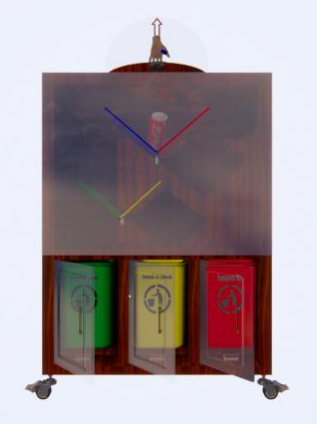

Fig 2. Design of Monitoring and Separating Dustbin System

\section{B. Soerting System}

In this sorting system, there are 3 stages, namely:

- First Stage: Sorting metal and non-metal waste using an Inductive proximity sensor.

- Second Stage: After the first stage of sorting, nonmetal waste will be further sorted into organic and non-organic using a capacitive proximity sensor.

- Third Stage: If the trash is full, the door will be locked automatically.

\section{Monitoring System}

The monitoring system uses a Node Mcu microcontroller as an intermediary between the janitor and the user, then it is connected to the load cell and infared as input. When the garbage is full, the infared will detect and the load cell will calculate the weight of the waste, then the data will be sent to the sanitation officer in the form of a full trash notification, the weight of the trash and als o the location of the trash.

\section{SYSTEM FunCTION}

\section{A. Architecture of System}

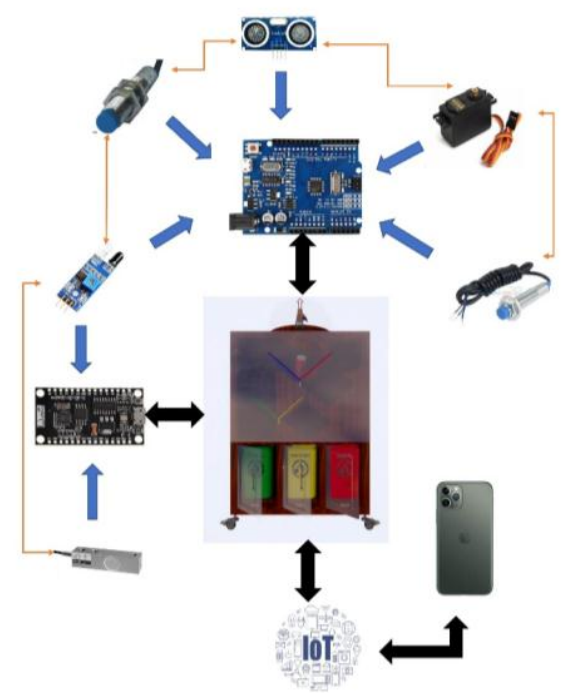

Fig 3. Architecture of System

(1) IoT (Internet of Things)

The monitoring system is an activity that occurs in a high-level area which is carried out so that measurements can be made through time which 
shows the movement towards a goal or away from that goal. The purpose of monitoring itself is so that activities are controlled according to plan and in accordance with proper procedures. The monitoring system will provide information about the status and the tendency that measurements and evaluations are repeated over time, if something is not desired, the results will be directly generated by the monitoring system without internupting the process. IoT is a concept that has the ability to transfer data objects over a network without requiring human-to-human or human-to-computer interaction. IoT has evolved from the convergence of wireless technologies, micro-electromechanical systems (MEMS), and the Internet [9].

(2) Components of The System

a) Microcontroller

This device uses two microcontrollers, namely:

1) Arduino Uno

Arduino Uno is a board that uses the ATmega328 microcontroller. The Arduino Uno has 14 digital pins (6 pins can be used as PWM outputs), 6 analog inputs, a $16 \mathrm{MHz}$ crystal oscillator, a USB connection, a power supply connector, an ICSP header, and a reset button. Arduino Uno contains everything needed to support a microcontroller. Just connecting it to a computer via USB or providing DC voltage from a battery or AC to DC adapter can make it work. The Arduino Uno uses the ATmega16U2 programmed as a USB to serial converter for serial communication to a computer via the USB port. "Uno" means one in Italian and was named to mark the release of Arduino 1.0. Version 1.0 is the reference version of Arduino in the future. The Arduino Uno R3 is the latest revision of the Arduino board series, and the reference model for the Arduino platform[10].

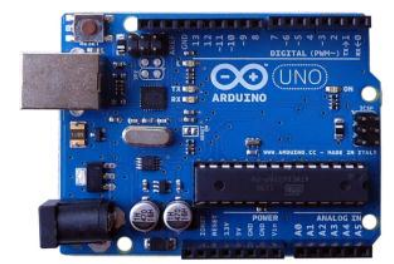

Fig 4. Arduino Uno

2) ESP $8266 /$ Node Mcu

The ESP8266 module is one of the most effective tools for communication or control over the intemet, whether used as a standalone or by using an additional microcontroller. In this case Arduino is used as a controller. This module is classified as a system on chip which does not always require a microcontroller to control the output. Arduino is usually connected as a connecting bridge accessed via the intemet via wifi communication [11].

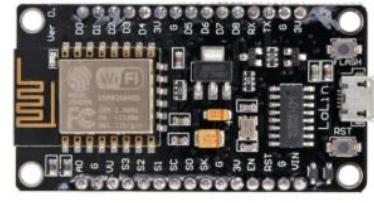

Fig 5. Node Mcu

b) Proximity Sensor

Proximity literally means distance or proximity, so the meaning of proximity sensor is a sensor that can detect the presence of objects that are nearby without going through physical contact.

1) InductiveProximity Sens or

More specifically, the inductive proximity sensor is a proximity sensor that can detect metal objects without touching them. Inductive proximity sens or operates using the induction principle. Inductance is a condition in which a fluctuation of electric current flowing in a magnetic material induces an electromotive force (emf) of an object / target in the form of metal [12].

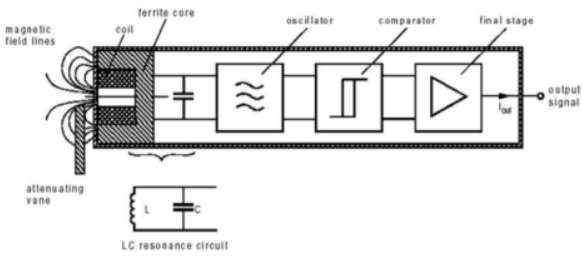

Fig 6. Inductive Proximity Sens or

Inductive Proximity sensor consists of four basic elements as shown in the picture, the four elements on the Inductive Proximity sens or are:

- Sensor coil and ferrite core

- Ocsillator circuit

- Detection circuit (comperator)

- Solid state output circuit

Principle of Operation for Inductive Proximity Sensor:

The oscillator circuit generates electromagnetic field frequency waves from the ferrite core radiation and coil assembly. The magnetic field exists around the axis of the ferrite core. When the metal object approaches the field, eddy currents are induced on the target surface causing a loading effect or "damping", this causes a reduction in the amplitude of the oscillator signal. The detection circuit detects changes in the oscillator amplitude, the detection circuit which functions like a switch will short when the amplitude changes on the oscillator amplitude reach a certain value. The ON signal from the detection circuit will turn the solid-s tate output ON. Vice vers a to make the output s witch OFF. Other methods include an Aluminum Detection Sensor, which detects phase frequency, and an All-metal Sensor, which uses a coil, which works to detect only 
changing components of impedance / resistance. There are also Pulse-response Sensors, which generate eddy currents in pulses and detect the time change in eddy current with the induced voltage in the coil.

Related Work:

Based on the previous research joumal, conducted by Abdul Rohman and Ayu Subandi, the results of testing the inductive proximity sensor with various metal waste have a $100 \%$ success percentage, with as many as 20 tests [13].

2) Capacitive Proximty Sens or

Capacitive Proximity Sensors can be used to detect metal as well as non-metallic targets such as paper, wood, plastic, glass, wood, powder, and liquid.etc without physical contact. Capacitive Proximity Sensor senses the object "target" due to the target's ability to be charged with electricity. Since even nonconductors can withstand a charge this means that almost any object can be detected with this type of sensor [14].

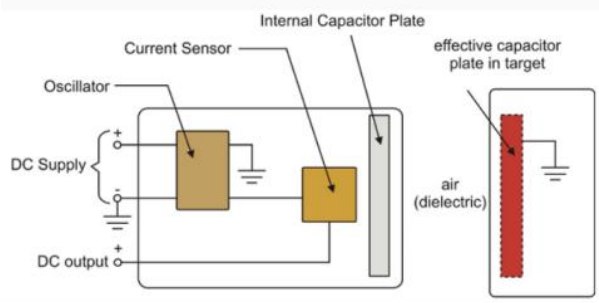

Fig 7. Capacitive Proximity Sens or

Capacitive Proximity sensor cons ists of four basic elements as shown in the picture, the four elements on the Capacitive Proximity sens or are:

- Plate

- Oscillator circuit

- Threshold Detector

- Output circuit

Principle of Operation for Capacitive Proximity Sensor:

Capacitive proximity sensor works on the principle of a capacitor. Capacitive proximity sensor detects changes in capacitance between sensing object and sensor. The amount of capacitance varies depending on the size and distance of the sensing object. The plate inside the sensor acts as one plate capacitor and the target acts as another plate and the water acts as a dielectric between the plates. As the object approaches the capacitor plate, the capacitance increases and as the object moves away, the capacitance decreases. The detector circuit checks the amplitude output of the oscillator and based on it the output $\mathrm{s}$ witches. Capacitive sensors can detect targets whose dielectric constant is greater than air. The change in the resulting capacity between these two poles was detected.

Related Work:
Based on the previous research joumal, conducted by Abdul Rohman and Ayu Subandi, the test results of capacitive proximity sensors with various non-metallic was te have a success percentage of $80 \%$, with 20 tests, both organic and non-organic waste[13].

c) Ultrasonic Sensor

An ultrasonic sensor is a sensor that utilizes ultrasonic waves which has a function to convert physical quantities or sound into electrical quantities and vice versa. The working principle of an ultrasonic sensor is based on the emission of waves that go to a target and then the waves bounce back towards the sensor. One of the ultrasonic sensors can be used to define distance or existence an object with a certain frequency [15].

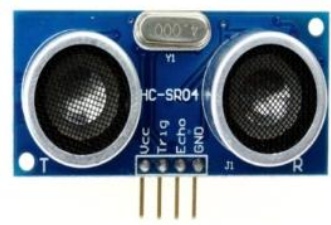

Fig 8. Ultras onic Sensor

d) IR Obstacle Sensor

IR Obstacle Infrared sensor is a module that detects obstacles or objects in front of it. The components in this sensor cons ist of an IR emitter and an IR receiver / phototrans is tor [16]. The way it works is when the power-up, the IR emitter will emit infrared light, which is not visible, the light is then reflected by the object in front of it. This reflected light is then received by the IR receiver. There is an Op-Amp LM363 which functions as a comparator between the IR receiver resistance and the sensitivity regulator trimpot resistance. When exposed to infrared light reflected by the object earlier, the IR receiver's resistance will decrease so that the Op-Amp output becomes high / 5V and turns on the sensor LED. The opamp output is also connected to the "OUT" pin which is connected to the Arduino.

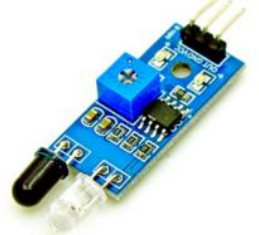

Fig 9. IR Obstacle Sensor

e) Load Cell

Load Cell is designed to detect a load weight. If the load cell is loaded on the iron core, the resistance value in the strain gauge will change. In general, the load cell consists of 4 cables where two cables are for excitation and the other two cables are the output signal. Based on the findings of Robert Hooke, the effect relationship between mechanical stress and deformation is called strain. This strain occurs in the skin layer 
of the material and the force caused by this strain is measured using a strain sensor or strain gauge [17].

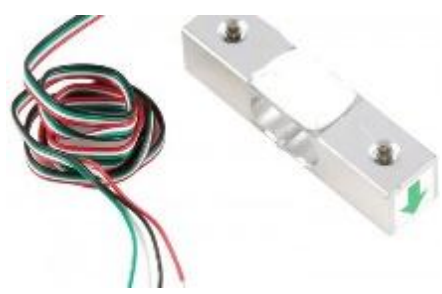

Fig 10. Load Cell

f) Servo Motor

Servo motors are self-contained electrical devices, which rotate machine parts with high efficiency, high precision and use an ordinary motor to pair them with sensors for feedback. The servo motor is designed with a closed loop system. The use of a closed loop control system on the servo motor is useful for controlling the movement and final position of the servo motor shaft [18].

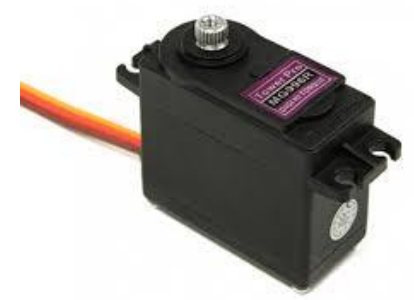

Fig 11. Servo Motor

\section{B. Implementation of System}

(1) Sorting SystemDevice

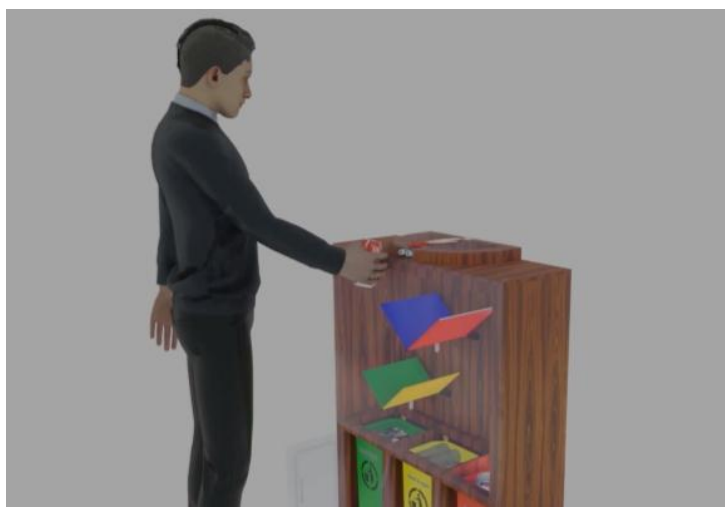

Fig 11. Sorting SystemDevice

This device work, in a few step:

a) When there is trash approaching, the trash can lid will open automatically

b) Then, the waste is entered and goes to the first sorting, namely sorting metal and non-metal waste using an Inductive Proximity sensor

c) Inductive proximity sensor will send a signal to the servo to move 90 degrees to the right if the trash is metal, and vice versa

d) After sorting the first stage goes to the second stage of sorting, namely sorting organic and nonorganic waste using a Capacitive Pro ximity sensor e) Capacitive Proximity Sensor will send a signal to the servo to move 90 degrees to the left if the waste is organic and vice versa.

(2) Monitoring SystemDevice
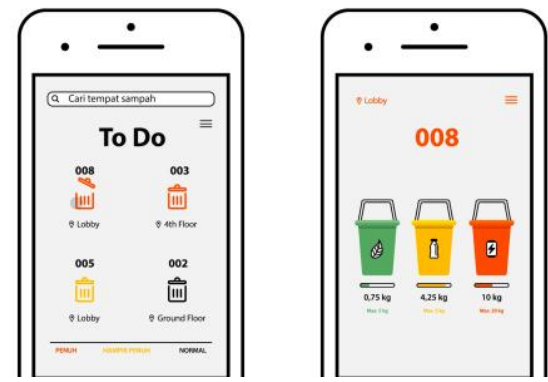

Fig 11. Monitoring SystemDevice

This device work, in few steps:

a) When it has passed the waste sorting stage, every was te that enters its weight will be calculated by a weight sensor

b) Then when the trash is full, the infared sensor will light up

c) Furthermore, after the infared lights up, the NodeMcu microcontroller will send a notification to the user that the trash is full and the total trash weight and pickup location will also be visible.

\section{CONCLUSION}

This paper proposes the sophistication of waste in industry 4.0, where is dustbin can open automatically, sort out the garbage automatically, detect the trash when it is full and calculate the weight of the garbage. The dustbin is connected to the cleaning officer's phone by utilizing the esp 8266 as an IoT.

Monitoring and separating dusbin is proposed to be a digital productbecause:

1. There is an automatic garbage sorting based, people no longer need to choose which garbage can suits the type of garbage they dispose of because there is automatic sorting of garbage by using proximity inductive and capacitive.

2. Monitoring and separating dustbin automatically can minimize unpleasant odor that issued by the organic waste.

3. Easy in conveying information to cleaning officers and optimizes the cleaning officer's work because it is connected with IoT.

4. There is an infrared sensor above the trash, which serves for detection of the height of the trash. If the trash is full, then the sensor will light up and the dustbin can't be open.

5. There is a load cell at the bottom of the trash that is useful for cleaning officer to determine the weight of the waste, so that it can estimate the equipment needed and in accordance with the weight of the garbage.

6. Has a transparent design which indirectly educate public about the importance of waste sorting. 


\section{ACKNOWLEDGMENT}

The author would like to thank all those who have helped in completing this joumal, especially the UNS academic community who have supported and provided many suggestions to the author.

\section{REFERENCES}

[1] Kementrian Lingkungan Hidup dan Kehutan an RI : Gerakan Nasional Pilah Sampah Dari Rumah Resmi Diluncurkan. 2019. https://www.menlhk.go.id/site/single_post/2379

[2] IPB University: Indonesia is the Second Largest Plastic Waste Contributor in the World. 2018. https://ipb.ac.id/news/index /2018/10/indonesia-is-the-second-larg est-plastic-w aste-contributor-inthe-world/65b58e2ccb3ffe42 cd0470ea3624b018

[3] Hari Bhakta Sharma, Kumar Raja Vanapalli. Challenges, opportunities, and innovations for effective solid waste management

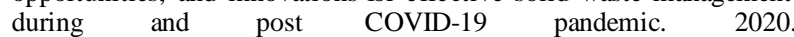
https://www.ncbi.nlm.nih.gov/pmc/articles/PMC7362850/

[4] Dedi Setiawan 2018 Rancang Bangun Alat Pembuka dan Penutup Tong Sampah Otomatis Berbasis Mikrokontroler. http://is.its.ac.id/pubs/oajis/index.php/home/detail/ 1289/RANCANGBANGUNALAT-PEMBUKA-DAN-PENUTUP-TONG-SAMPAHOTOMATIS-BERBASIS-MIKROKONTROLER

[5] Faisal I P 2019 Perancangan Prototype Alat Pemilah Sampah Otomatis .http://jurnal.umsu.ac.id/index.php/RELE/article/view/3645.
[6] Bioenable 2019 Smart Bins for Smart City. https:// www.bioenabletech.com/smart-bins-for-smart-city.html

[7] Sensoneo: Smart Waste Management System 2019. https://sensoneo.com/press/

[8] Nugroho Panji, 2013. Panduan Membuat Kompos Cair. Jakarta: Pustaka baru Press.

[9] Yudhanto, Yudha.2015. Apa itu IoT (Internet of Thing). Surakarta.

[10] Aduino Uno Rev 3. https://store.arduino.cc/usa/arduino-uno-rev3

[11] Apa itu modul esp 8266. https://www.nyebarilmu.com/apa-itu-modulesp8266/.

[12] Yi-Xin Guo, Cong Lai, Zhi-Biao Shao, Kai-Liang Xu, and Ting Li. 2019. Differencial Structure of Inductive Proximity Sensor.https://www.researchgat e.net/publication/333065570_ Differential_Structure_of_Inductive_Proximity_Sensor

[13] Rohman, Abdul and Ayub Subandi. 2017. Rancang Bangun Pemilahan Sampah Skala Kecil Berbasis Mikrokontroler Secara Otomatis. https://repository.unikom.ac.id/53739/

[14] Capacitive Proximity Sensors Theory of Operation. 2018. http://www.softnoze.com/ downloads/Sensor\%20Basics\%203.pdf

[15] What is an Ultrasonic Sensor. 2019. https://www.keyence.com/ss/products/sensor/ sensorbasics/ultrasonic/info/

[16] IR Sensor.2015.https://www.electronicshub.org/ir-sensor/

[17] Load Cell. 2017.https://www.omega.co.uk/prodinfo/load-cells.html

[18] Servo Motor: types and working principle explained. 2018. https://engineering.eckovation.com/servo-motor-types-workingprinciple-explained/ 